\title{
Relation of normal body temperature with cheek dimples
}

\begin{abstract}
The purpose of current study was to spot the relation of normal body temperature with cheek dimples. Body temperature is defined as the ability of our body to generate heat. Our body maintains its temperature within a moderate range even the outer temperature of environment is change. Thermometer is a device used to measure body temperature either in Fahrenheit $\left({ }^{\circ} \mathrm{F}\right)$ or degree Celsius $\left({ }^{\circ} \mathrm{C}\right)$. We can measure body temperature from different parts of our body. Cheek dimples appear on our face when we smile or make any facial expression. Dimples are actually deformation of skin muscles. Deformation in double zygomatic muscle of face leads to the formation of cheek dimples. After taking consent we measure their body temperature with the help of a digital thermometer. Then we asked them whether they have dimples on their cheeks or not? We wrote their answers on a separate sheet along with their body temperatures. Total 160 subjects were participated in this movement. These subjects were students at Bahauddin Zakariya University Multan, Pakistan. Our study concluded that there is no scientific relation among normal body temperature and cheek dimples. ${ }^{1-4}$
\end{abstract}

Keywords: cheek dimples, normal body temperature, dimples and body temperature
Volume 3 Issue 2 - 2019

\section{Muhammad Imran Qadir, Hafiz Muhammad Noman Ajmal \\ Institute of Molecular Biology and Biotechnology, Bahauddin Zakariya University, Multan, Pakistan}

Correspondence: Hafiz Muhammad Noman Ajmal, Institute of Molecular Biology and Biotechnology, Bahauddin Zakariya University, Multan, Pakistan, Email junaidajmal784@gmail.com

Received: February 16, 2019 | Published: April 01, 2019

\section{Introduction}

Body temperature is defined as the ability of our body to generate heat. Our body maintains its temperature within a moderate range even the outer temperature of environment is change. Like when we are feeling too hot, our body starts sweating to maintain its temperature within optimum range and the evaporation of sweat cools our body. ${ }^{5}$ When we feel too cold, the surface area of our blood vessels reduced to save heat by decreasing blood flow. We start shivering and by trembling of muscles our body generate more heat. Normal temperature of human body is $98.6^{\circ} \mathrm{F}$ or $37^{\circ} \mathrm{C}$. It is an average body temperature and it may be above or below $1^{\circ} \mathrm{F}$ or $0.6^{\circ} \mathrm{C}$ depending upon the activity of body. Thermometer is a device used to measure body temperature either in Fahrenheit $\left({ }^{\circ} \mathrm{F}\right)$ or degree Celsius $\left({ }^{\circ} \mathrm{C}\right)$. We can measure body temperature from different parts of our body like armpit, mouth, the ear and the forehead. ${ }^{6}$ To take temperature reading from rectum is the most accurate way of measuring body temperature. If body temperature is less than the normal body temperature, this condition is said to be hypothermia. There are different reasons of hypothermia like being out in cold or excessive use of alcohol and some disorders like low thyroid. If body temperature is more than normal body temperature, this condition is known as fever or heatstroke. When heatstroke occurs human body fails to control its temperature within normal range and the temperature of the body keep rising. Heatstroke is deadly even it cause dehydration and the organs of body stop working. We need special medical treatment whenever we face this conditions. ${ }^{7-9}$

Cheek dimples appear on our face when we smile or make any facial expression. Dimples are actually deformation of skin muscles. Deformation in double zygomatic muscle of face leads to the formation of cheek dimples. It appears as a hollow area on cheeks when we smile or make some facial expressions. Dimples are inherited from parents to offspring and controlled by dominant genes. If both parents have homozygous dominant genes for dimples than there is $100 \%$ chance of dimples in their child. Some scientists told that it is an irregular dominant trait and controlled by some other genes. People with homozygous dominant genes have dimples on their both sides of cheek but people with heterozygous genes have dimple on one side of their cheek. New born babies have dimples due to the presence of body fats on their skin but their dimples disappear when their body fats becomes mature because they are not inherited. Only inherited dimples can stay on cheeks for longer time due to the presence of dominant genes. Dimples are too attractive and beautiful and everyone wish to have dimples. There are some ways to reduce the size of dimples but we cannot remove them permanently. The purpose of current study was to spot the relation of normal body temperature with cheek dimples. ${ }^{10}$

\section{Material and methods}

\section{Designing of project}

First of all we obtain permission from each subject to measure their body temperature. After taking consent we measure their body temperature with the help of a digital thermometer. Then we asked them whether they have dimples on their cheeks or not? We wrote their answers on a separate sheet along with their body temperatures. Then we made two lists, one list containing body temperatures of those subjects who do not have cheek dimples and one list containing body temperature of those individuals who have cheek dimples. Total 160 subjects were participated in this movement. These subjects were students at Bahauddin Zakariya University Multan, Pakistan. ${ }^{11}$

\section{Statistical analysis}

To perform statistical analysis we use MS Excel software and t test was applied to evaluate results.

\section{Results and discussion}

Above Table 1 illustrate the normal body temperature (Average $\pm \mathrm{SD}$ ) of subjects with their $\mathrm{p}$ values. Male subjects have $96.4^{\circ} \mathrm{F}$ body temperatures with $2.97 \mathrm{SD}$ who do not have cheek 
dimples while male subjects have $97.5^{\circ} \mathrm{F}$ with $0.5 \mathrm{SD}$. Female subjects have $96.1^{\circ} \mathrm{F}$ body temperatures with $2.77 \mathrm{SD}$ who do not have cheek dimples while female subjects have $96.7^{\circ} \mathrm{F}$ with $0.5 \mathrm{SD}$ having cheek dimples. Combined result of male and females is $97^{\circ} \mathrm{F}$ with $1.5 \mathrm{SD}$ having dimples and $98^{\circ} \mathrm{F}$ with $2.0 \mathrm{SD}$ not having dimples. $P$ values of males, females and combined is $0.35,0.22$ and 0.28 . Questionnaire based studies have brought a considerable enhancement in recent studies. ${ }^{12-15}$

Table I Relation of normal body temperature (Average \pm SD) to cheek dimples

\begin{tabular}{llll}
\hline Gender & Dimples & No dimples & P value \\
\hline Male & $96.4 \pm 2.97$ & $97.5 \pm 0.5$ & 0.35 \\
Female & $96.1 \pm 2.77$ & $96.7 \pm 2.35$ & 0.22 \\
Combined & $97 \pm 1.5$ & $98 \pm 2.0$ & 0.28
\end{tabular}

( $P>0.05$ hence $P$ considered as non-significant)

\section{Conclusion}

Our study concluded that there is no scientific relation among normal body temperature and cheek dimples because $P>0.05$ so result is non-significant.

\section{Acknowledgments}

None.

\section{Conflicts of interest}

The author declares there is no conflict of interest.

\section{References}

1. Johnson HA, Pavelec M. Thermal injury due to normal body temperature. Am J Pathol. 1972;66(3):557-564.

2. Syred N, Khalatov A, Kozlov A. Effect of surface curvature on heat transfer and hydrodynamics within a single hemispherical dimple. InASME Turbo Expo 2000: Power for Land, Sea, and Air 2000 May 8 (pp. V003T01A044-V003T01A044). American Society of Mechanical Engineers. 2000.
3. Ghosh S, Choudhury D, Roy T. Tribological investigation of diamondlike carbon coated micro-dimpled surface under bovine serum and osteoarthritis oriented synovial fluid. Science and technology of advanced materials. 2015;16(3):035002.

4. Satinoff E. Salicylate: action on normal body temperature in rats. Science. 19725;176(4034):532-533.

5. Sund-Levander M, Forsberg C, Wahren LK. Normal oral, rectal, tympanic and axillary body temperature in adult men and women: a systematic literature review. Scand J Caring Sci. 2002;16(2):122-128.

6. Mackowiak PA, Wasserman SS, Levine MM. A critical appraisal of 98.6 $\mathrm{F}$, the upper limit of the normal body temperature, and other legacies of Carl Reinhold August Wunderlich. JAMA. 1992;268(12):1578-1580.

7. Qadir MI, Javid A. Awareness about Crohn's Disease in biotechnology students. GloAdv Res J Med Medical Sci. 2018;7(3):062-064.

8. Qadir MI, Saleem A. Awareness about ischemic heart disease in university biotechnology students. GloAdv Res J Med Medical Sci. 2018;7(3):059-061.

9. Qadir MI, Ishfaq S. Awareness about hypertension in biology students. Int J Mod Pharma Res. 2018;7(2):08-10.

10. Qadir MI, Mehwish. Awareness about psoriasis disease. Int $J$ Mod Pharma Res. 2018;7(2):17-18.

11. Qadir MI, Shahzad R. Awareness about obesity in postgraduate students of biotechnology. Int J Mod Pharma Res. 2018;7(2):14-16.

12. Qadir MI, Rizvi M. Awareness about thalassemia in post graduate students. MOJ Lymphology \& Phlebology. 2018;2(1):14-16.

13. Qadir MI, Ghalia BA. Awareness survey about colorectal cancer in students of M. Phil Biotechnology at Bahauddin Zakariya

14. University, Multan, Pakistan. Nov Appro in Can Study. 2018;1(3):NACS.000514.2018.

15. Qadir MI, Saba G. Awareness about intestinal cancer in university student. Nov Appro in Can Study. 2018;1(3):NACS.000515.2018. 